ACTA UNIVERSITATIS WRATISLAVIENSIS

No 3780

Studia nad Autorytaryzmem i Totalitaryzmem 39, nr 2

Wrocław 2017

DOI: $10.19195 / 2300-7249.39 .2 .8$

EWELINA ROGALSKA

Uniwersytet im. Adama Mickiewicza w Poznaniu

MICHAŁ URBAŃCZYK

Uniwersytet im. Adama Mickiewicza w Poznaniu

\title{
Złożoność zjawiska mowy nienawiści w pozaprawnym aspekcie definicyjnym
}

O mowie nienawiści trudno pisać z kilku względów. Po pierwsze, jest to zjawisko wieloaspektowe. O mowie nienawiści można mówić chociażby w aspekcie prawnym - zjawisko to można wtedy opisywać językiem karnoprawnym, cywilnoprawnym ${ }^{1}$, konstytucyjnoprawnym językiem ochrony praw człowieka, a nawet w kontekście administracyjnoprawnym ${ }^{2}$ i prawa pracy. Jednak mowa nienawiści obecna jest także na polu badań politologicznych, kulturowych, pedagogicznych, lingwistycznych czy socjologicznych. Każdy z tych dyskursów będzie się różnił od siebie m.in. wskutek uwzględniania innych perspektyw badawczych, używania innych narzędzi metodologicznych czy innego języka.

Po drugie, $\mathrm{z}$ racji swojej istoty interesujące nas zjawisko jest różnie definiowane. W dalszej części tekstu przedstawionych zostanie wiele reprezentatywnych definicji, które zaistniały w polskiej debacie publicznej. Już ich pobieżna lektura uświadamia wielość problemów, jakie stoją przed każdym, który podejmuje się trudu zdefiniowania mowy nienawiści.

Wreszcie, po trzecie, termin „mowa nienawiści” jest często używany w odniesieniu do różnych zjawisk, a ich różnorodność najlepiej widać właśnie przy próbach zdefiniowania. Sergiusz Kowalski wskazal, że jednocześnie może to być „istniejące obiektywnie zjawisko dające się wyodrębnić w sensowny sposób

${ }^{1} \mathrm{Na}$ temat cywilnoprawnych aspektów ochrony przed mową nienawiści zob. szerzej K. Pałka, M. Kućka, Ochrona przed mowa nienawiści - powództwo cywilne czy akt oskarżenia?, [w:] Mowa nienawiści a wolność słowa. Aspekty prawne i społeczne, red. R. Wieruszewski et al., Warszawa 2010, s. 42-54.

${ }^{2} \mathrm{Na}$ temat administracyjnoprawnych instrumentów walki z mową nienawiści zob. szerzej M. Krotoszyński, Trzecia droga: środki administracyjne w zwalczaniu mowy nienawiści, [w:] Mowa nienawiści a wolność stowa..., s. 114-127. 
spośród ogółu społecznych praktyk językowych, czy też zjawisko nieco inne, choć też ważne - to, czym zajmują się de facto [...] organizacje pozarządowe (co też jest zjawiskiem społecznym)"3.

Dopełnić obrazu trudności piętrzących się przed badaczami mowy nienawiści z pewnością może świadomość istnienia odmiennych (często konkurencyjnych) tradycji określania granic wolności słowa (amerykańska i europejska ${ }^{4}$, ponadnarodowa - europejska i poszczególnych państw). Na koniec trzeba dodać, że termin „mowa nienawiści” stał się też narzędziem manipulacji ${ }^{5}$ i walki na polu ideologicznym oraz uległ upolitycznieniu 6 .

W ten sposób mamy do czynienia z sytuacją, która skutkuje trudnościami we właściwym zdefiniowaniu mowy nienawiści jako pewnego zjawiska zarówno prawnego, jak i społeczno-politycznego. Celem niniejszego artykułu jest przedstawienie wybranych definicji mowy nienawiści funkcjonujących poza doktryną prawa karnego. Takie zestawienie pozwoli na wskazanie podobieństw oraz wychwycenie różnic w postrzeganiu mowy nienawiści w sferze publicznej, zwłaszcza

${ }^{3}$ S. Kowalski, Obecność mowy nienawiści w życiu społecznym i debacie publicznej, [w:] Mowa nienawiści a wolność słowa..., s. 239.

${ }^{4} \mathrm{Na}$ interesującą odmienność między tymi tradycjami wskazała Dorota Śledzińska-Simon, która przypomniała, że w Stanach Zjednoczonych karalna jest wypowiedź nawołująca do przemocy, natomiast w Europie - wypowiedź nawołująca do nienawiści. Dodatkowo, w niektórych państwach europejskich karalna jest także wypowiedź, która wyraża pogardę lub zniewagę (D. ŚledzińskaSimon, Decyzja ramowa w sprawie zwalczania pewnych form i przejawów rasizmu i ksenofobii jako trudny kompromis wobec mowy nienawiści w Unii Europejskiej, [w:] Mowa nienawiści a wolność stowa..., s. 98).

5 Interesujący przykład manipulacji słowami w debacie publicznej podała Anna Cegieła przykład polegający na posługiwaniu się wyrazami, których odbiorca nie rozumie wystarczająco dobrze, a które są mocno nacechowanie negatywne: „Określając kogoś mianem faszysty, rasisty, nazisty, nadawca nie liczy wcale na to, że odbiorca wie, czym te pojęcia się różnią i co dokładnie oznaczają. Zdaje sobie natomiast sprawę z tego, że określenia te wartościują negatywnie i że reakcją odbiorcy na nazwanie kogoś faszystą albo nazistą będzie niechęć do tej osoby. Świadomie go w ten sposób piętnuje. Do grupy tak wykorzystywanych wyrazów należą rzeczowniki: eksterminacja, mow a ni en aw iś c i [wyr. - E.R., M.U.], getto, nazizm, stalinizm i stalinista, fundamentalizm i fundamentalista oraz przymiotniki: stalinowski, faszystowski i smoleński oraz wiele innych" (eadem, Stowa i ludzie, Warszawa 2014, s. 107).

${ }^{6}$ Szerzej na ten temat zob. J. Piskorski, Polityzacja mowy nienawiści, niepublikowany referat wygłoszony w czasie II Międzynarodowej Konferencji „W poszukiwaniu europejskiej doktryny wolności słowa", 23-24 marca 2017 r., Wydział Prawa i Administracji Uniwersytetu im. Adama Mickiewicza w Poznaniu (więcej na temat konferencji zob. m.in.: [Redakcja Wprost], Jak ma się mowa nienawiści do wolności słowa? Co wolno napisać nam w internecie? Odpowiedza prawnicy, https:// www.wprost.pl/zycie/10046470/II-Miedzynarodowa-Konferencja-pt-W-poszukiwaniu-europejskiejdoktryny-wolnosci-slowa.html [dostęp 1.05.2017]; [Przegląd], Międzynarodowa Konferencja pt. „W poszukiwaniu europejskiej doktryny wolności słowa”, https://www.tygodnikprzeglad.pl/ miedzynarodowa-konferencja-pt-poszukiwaniu-europejskiej-doktryny-wolnosci-slowa/ [dostęp: 1.05.2017], Free Speech, edycja II, http://prawo.amu.edu.pl/strona-glowna/jednostki-organizacyjne/katedry/Katedra-Doktryn-Polityczno-Prawnych-i-Filozofii/freespeechpoznan-edycja-ii [dostęp: 1.05.2017]). 
tych wywołujących spory w procesie stosowania prawa. Najbardziej widoczne jest to w kontekście konfliktu między prawem karnym (dla którego w tym wypadku najistotniejsze są znamiona czynu zabronionego) a organizacjami walczącymi z mową nienawiści (dla których istotniejszymi wartościami są np. uczucia pokrzywdzonych ${ }^{7}$ ).

Ogólnie problematyczne jest używanie właściwego terminu. Często w omawianym kontekście używa się sformułowań „przestępstwa mowy nienawiści”, „przestępstwa (z) nienawiści”, ,przestępstwa motywowane uprzedzeniami” (ang. biased-motivated crimes). Zakres pojęciowy tych terminów jest różny, a mimo to niejednokrotnie używa się ich zamiennie ${ }^{8}$. Zaciemnia to obraz i powoduje trudności z właściwą oceną zjawisk.

Zarówno $\mathrm{w}$ anglosaskiej literaturze przedmiotu, jak i tamtejszej praktyce organów ścigania ${ }^{9}$ odróżnia się przestępstwo nienawiści (hate/bias crime) od incydentu z nienawiści (hate/bias incident); powyższe rozróżnienie przyjęto także na gruncie polskim ${ }^{10}$. Incydentem jest jakiekolwiek zajście, które może (choć nie musi) być przestępstwem i które osoba pokrzywdzona odbiera jako opresję motywowaną uprzedzeniami lub nienawiścią ${ }^{11}$. Przestępstwem z nienawiści jest natomiast każdy incydent stanowiący przestępstwo, który jest postrzegany przez osobę pokrzywdzoną lub przez inną osobę jako zdarzenie motywowane uprzedzeniami lub nienawiścią ${ }^{12}$.

7 „Podejmując temat mowy nienawiści, warto mieć szczególnie na uwadze konsekwencje nienawistnego języka dla jego ofiar, czyli grup mniejszościowych. Przeprowadzane w Stanach Zjednoczonych badania psychologiczne dowiodły, że u grup imigranckich narażonych na mowę nienawiści częściej dochodziło do samobójstw. Bycie narażonym na codzienną konfrontację z obraźliwymi etykietkami podwyższało skłonność do samobójstw niezależnie od tego, jak częste były samobójstwa w kraju pochodzenia danej grupy etnicznej. »Model krzywdzącego języka« sformułowany przez Laurę Leets i Howarda Gilesa (1997) wyjaśnia, jak mniejszości reagują na mowę nienawiści. Reakcje te przypominają każde inne traumatyczne przeżycie. Najpierw, na skutek utraty godności, pojawiają się silne reakcje emocjonalne: przygnębienie, gniew i smutek. Później następują próby zrozumienia tego doświadczenia oraz przypisania za nie odpowiedzialności. $\mathrm{Z}$ czasem u ofiar pojawia się nienawiść i żal. Emocje te mogą prowadzić do agresji wobec sprawców mowy nienawiści, jednak częściej są tłumione i wtedy pojawia się depresja, wyuczona bezradność, w końcu uzależnienia - narkomania czy alkoholizm” (M. Bilewicz et al., Mowa nienawiści. Raport z badań sondażowych, Warszawa 2014, s. 8).

8 Np. M. Płatek, Mowa nienawiści - przesłanki depenalizacji, [w:] Mowa nienawiści a wolność stowa..., s. 55-92.

9 Przykładowo Hate Crime Operational Guidance, College of Policing Limited, Coventry 2014; Hate crime and the law. A briefing paper, Anti-Bullying Alliance, London 2016; Homophobic hate crimes and hate incidents. Equality and Human Rights Commission 2009. Responding to Hate Crime. A Multidisciplinary Curriculum, National Center for Hate Crime Prevention, Washington 2000.

${ }^{10} \mathrm{~Np}$. Ł. Szwejkowski, Przestępstwa z nienawiści. Wybrane zagadnienia, materiały dydaktyczne Centrum Szkolenia Policji, Legionowo 2012.

11 M. Płatek, op. cit., s. 84.

12 Zgodnie z definicją Biura Instytucji Demokratycznych i Praw Człowieka (ODIHR) przestępstwo z nienawiści to każde przestępstwo natury kryminalnej, wymierzone w ludzi i ich mienie, 
Podobnie jednak powinno się potraktować sferę wypowiedzi. Skoro wyróżnia się przestępstwa mowy nienawiści, tj. te przestępstwa z nienawiści, które popełnianie są poprzez rozpowszechnianie określonych wypowiedzi, to należy wskazać również szerszą kategorię, czyli rozpowszechniane wypowiedzi, które mogą (choć nie muszą) być przestępstwem i które osoba pokrzywdzona odbiera jako słowną opresję motywowaną uprzedzeniami lub nienawiścią. W ten sposób niejako otrzymujemy cztery zjawiska w przestrzeni publicznej, zarówno politycznej, społecznej, jak i prawnej, mające pewne części wspólne ${ }^{13}$.

Należy podkreślić, że terminu „mowa nienawiści” nie ma w polskim języku prawnym, aczkolwiek jest już trwałym elementem języka prawniczego (orzecznictwa i doktryny prawa). Jak jednak zauważa się w doktrynie prawa karnego, „optyka właściwa naukom prawnym ogranicza pole widzenia jedynie do tych zachowań, które naruszają normę sankcjonującą zawartą w przepisach prawa karnego"14. I choć poza zainteresowaniem niniejszego artykułu jest definiowanie mowy nienawiści w orzecznictwie, warto zauważyć, że także tam pojawiają się różne terminy. Przykładowo, w wyroku Sądu Okręgowego w Katowicach z 23 września 2009 r. (sygn. akt III C 286/08) można znaleźć sformułowanie ,język nienawiści”, pojmowany jako język szczególnie obraźliwy, pogardliwy i godzący w dobra osobiste drugiej osoby, zaś w uzasadnieniu mowa nienawiści została zdefiniowana jako „wyrażanie uczuć silnej niechęci lub wręcz wrogości wobec konkretnej osoby”.

Jak już zauważono wcześniej, kodeks karny posługuje się innymi zwrotami. W art. $256 \S 1$ k.k. penalizuje dwa rodzaje zachowań. Po pierwsze, publiczne propagowanie faszystowskiego lub innego totalitarnego ustroju państwa oraz publiczne nawoływanie do nienawiści na tle różnic narodowościowych, etnicznych, rasowych, wyznaniowych albo ze względu na bezwyznaniowość. Natomiast w art. 257 k.k. penalizowane jest znieważenie osoby lub grupy osób na tle różnic

w wyniku którego ofiara lub inny cel przestępstwa są dobierane ze względu na ich rzeczywiste bądź domniemane powiązanie lub udzielanie wsparcia grupie wyróżnianej na podstawie cech charakterystycznych wspólnych jej członkom, takich jak faktyczna lub domniemana rasa, narodowość lub pochodzenie etniczne, język, kolor skóry, religia, płeć, wiek, niepełnosprawność fizyczna lub psychiczna, orientacja seksualna lub inne podobne cechy (Preventing and responding to hate crimes, OSCE - ODIHR, Warszawa 2009, s. 15, cyt. za: Przemoc motywowana uprzedzeniami. Przestępstwa z nienawiści, red. A. Lipowska-Teutsch, E. Ryłko, Kraków 2007, s. 11).

13 Jak zauważył Mateusz Woiński: „nie ulega wszakże kwestii, że określenia »przestępstwo z nienawiści« i »mowa nienawiści« mają różny zakres desygnatów. Przestępstwem z nienawiści może być jedynie zachowanie człowieka zabronione przez ustawę pod groźbą kary jako zbrodnia lub występek, bezprawne, zawinione i społecznie szkodliwe w stopniu wyższym niż znikomy, podjęte ze względu na określoną cechę ofiar wskazującą na jej przynależność grupową [...]. Nie każdy zaś akt mowy (czy szerzej akt komunikacji werbalnej) stanowi czyn zabroniony. Z drugiej strony nie każde przestępstwo $\mathrm{z}$ nienawiści jest realizowane $\mathrm{w}$ formie werbalnej. Pomiędzy zakresami desygnatów omawianych nazw zachodzi zatem stosunek krzyżowania się. Proponuję, aby kategorię leżącą w płaszczyźnie przecięcia określać jako przestępstwo mowy nienawiści" (idem, Prawnokarne aspekty zwalczania mowy nienawiści, Warszawa 2014, s. 31-32).

14 Ibidem, op. cit., s. 23. 
narodowościowych, etnicznych, rasowych, wyznaniowych albo ze względu na bezwyznaniowość.

O ile mowa nienawiści nie pojawia się w ustawodawstwie polskim, o tyle jest obecna w przepisach prawa międzynarodowego i europejskiego. Jedna z pierwszych definicji mowy nienawiści została zawarta w załączniku do rekomendacji Komitetu Ministrów Rady Europy nr R97/20 z 1997 r. Wedle niej:

mowa nienawiści obejmuje wszelkie formy wypowiedzi, które szerzą, propagują czy usprawiedliwiają nienawiść rasową, ksenofobię, antysemityzm oraz inne formy nienawiści bazujące na nietolerancji, m.in.: nietolerancję wyrażającą się w agresywnym nacjonalizmie i etnocentryzmie, dyskryminację i wrogość wobec mniejszości, imigrantów i ludzi o imigranckim pochodzeniu ${ }^{15}$.

\section{nie, iż \\ W innym miejscu systemu Rady Europy odnaleźć można stwierdze-}

ustne, pisemne, audiowizualne wypowiedzi, a także inne formy ekspresji, włączając media elektroniczne, podżegające do nienawiści, dyskryminacji czy przemocy wobec rasowych, etnicznych czy religijnych grup lub przeciwko ich członkom, na podstawie tego, że przynależą oni do takiej grupy, są prawnie sklasyfikowane jako przestępstwa karne, które mogą także obejmować produkcję, dystrybucję i przechowywanie w celu dystrybucji tych materiałów ${ }^{16}$.

Wreszcie w kontekście działań Rady Europy nie można zapomnieć o podpisanym przez Polskę w 2003 r. Protokole dodatkowym z 28 stycznia 2003 r. do Konwencji o cyberprzestępczości z $2001 \mathrm{r} .{ }^{17} \mathrm{~W}$ art. 2, pkt 1 protokołu znaleźć można definicję materiałów rasistowskich i ksenofobicznych, zgodnie z którą jest to

każdy materiał pisemny, każdy wizerunek lub każde inne wyrażenie myśli lub teorii, które nawołują, popierają lub podżegają do nienawiści, dyskryminacji lub przemocy przeciw jakiejkolwiek osobie lub grupie osób, ze względu na rasę, kolor, pochodzenie narodowe lub

15$, , $\mathrm{t}] \mathrm{h}$ he term »hate speech « shall be understood as covering all forms of expression which spread, incite, promote or justify racial hatred, xenophobia, anti-Semitism or other forms of hatred based on intolerance, including: intolerance expressed by aggressive nationalism and ethnocentrism, discrimination and hostility against minorities, migrants and people of immigrant origin" (Rekomendacja Komitetu Ministrów Rady Europy nr R97/20, https://rm.coe.int/CoERMPublicCommonSearchServices/DisplayDCTMContent?documentId=0900001680505d5b [dostęp: 25.01.2017]).

16 https://www.msz.gov.pl/resource/eceb6ab3-c4bd-4df8-8b6b-2e12b8395d91:JCR (dostęp: 10.05.2017).

17 Pełna nazwa to Protokół dodatkowy do Konwencji Rady Europy o cyberprzestępczości dotyczący penalizacji czynów o charakterze rasistowskim lub ksenofobicznym popełnionych przy użyciu systemów komputerowych, sporządzony w Strasburgu dnia 28 stycznia 2003 r. (Dz.U. z 2015 r. poz. 730). Dokument został opublikowany w Dzienniku Ustaw 27 maja 2015 r., a wszedł w życie 1 czerwca 2015 r. Konwencja Rady Europy o cyberprzestępczości, sporządzona w Budapeszcie 23 listopada 2001 r. (Dz.U. z 2015 r. poz. 728); Ustawa z 12 września 2014 r. o ratyfikacji Konwencji o cyberprzestępczości (Dz.U. z 2014 r. poz. 1514); Oświadczenie rządowe z 2 kwietnia 2015 r. w sprawie mocy obowiązującej Konwencji o cyberprzestępczości (Dz.U. z 2015 r., poz. 729). 
etniczne, jak również religię, jeżeli wykorzystywana jest ona jako pretekst dla któregokolwiek ze wskazanych wyżej zachowań.

Natomiast w art. 3-6 zawarto zobowiązania do uznania za przestępstwo takich działan, jak: rozpowszechnianie materiałów rasistowskich i ksenofobicznych w systemie komputerowym, groźby powodowane rasizmem i ksenofobią, zniewagi powodowane rasizmem i ksenofobią, zaprzeczanie lub poważne umniejszanie znaczenia, akceptacji lub usprawiedliwiania zbrodni ludobójstwa oraz zbrodni przeciwko ludzkości.

Pewne próby zdefiniowania przestępstw motywowanych nienawiścią w latach 90. podjęto też w kontekście walki z rasizmem i ksenofobią w ramach systemu Unii Europejskiej. W tym kontekście warto odnotować sformułowanie zawarte we Wspólnym działaniu Rady 96/443/WSiSW z 15 lipca 1996 r. dotyczącym działania w celu zwalczania rasizmu i ksenofobii, gdzie wskazano następujące zachowania:

1) publiczne podburzanie do dyskryminacji, przemocy lub nienawiści rasowej w odniesieniu do grup osób lub członków takich grup określonych ze względu na kolor skóry, rasę, wyznawaną religię albo pochodzenie narodowe lub etniczne;

2) publiczne akceptowanie, z powodów rasowych lub ksenofobicznych, przestępstw przeciwko ludzkości i łamania praw człowieka;

3) publiczna negacja przestępstw określonych w art. 6 Karty Międzynarodowego Trybunału Wojskowego dołączonej do Porozumienia londyńskiego z dnia 8 kwietnia 1945 r., o tyle, o ile obejmują one zachowania pogardliwe i poniżające w stosunku do grup osób określanych przez odniesienie do koloru skóry, rasy, wyznawanej religii lub pochodzenia narodowego lub etnicznego;

4) publiczne rozpowszechnianie lub dystrybuowanie opracowań, obrazów i innych materiałów będących wyrazem rasizmu i ksenofobii;

5) uczestnictwo w działalności grup, organizacji lub stowarzyszeń, dotyczącej dyskryminacji, przemocy lub nienawiści rasowej, etnicznej lub religijnej ${ }^{18}$.

Kontynuacją działań na polu prawa europejskiego była Decyzja ramowa Rady 2008/913/WSiSW z dnia 28 listopada 2008 r. w sprawie zwalczania pewnych form i przejawów rasizmu i ksenofobii za pomocą środków prawnokarnych, w której również znalazła się definicja przestępstw na tle rasistowskim i ksenofobicznym, jako następujących czynów popełnianych umyślnie:

1) publiczne nawoływanie do przemocy lub nienawiści skierowanej przeciwko grupie osób, którą definiuje się według rasy, koloru skóry, wyznawanej religii, pochodzenia albo przynależności narodowej lub etnicznej, lub przeciwko członkowi takiej grupy;

18 Wspólne działanie z dnia 15 lipca 1996 r. przyjęte przez Radę na podstawie art. K.3 Traktatu o Unii Europejskiej, dotyczące działania w celu zwalczania rasizmu i ksenofobii, 96/443/ WSiSW (Dz.U. Wspólnot Europejskich L 185/5 z 24 lipca 1996 r.; Dz.U. Unii Europejskiej 19, t. 1), https://bip.ms.gov.pl/Data/Files/_public/bip/prawo_eu/ue2/31996f0443pl.pdf (dostęp: 15.01.2017), s. 33-34. 
2) popełnienie czynu, o którym mowa w pkt 1), przez publiczne rozpowszechnianie lub rozprowadzanie tekstów, obrazów lub innych materiałów;

3) publiczne aprobowanie, negowanie lub rażące pomniejszanie zbrodni ludobójstwa, zbrodni przeciwko ludzkości oraz zbrodni wojennych w rozumieniu art. 6, 7 i 8 statutu Międzynarodowego Trybunału Karnego skierowanych przeciwko grupie osób, którą definiuje się według rasy, koloru skóry, wyznawanej religii, pochodzenia albo przynależności narodowej lub etnicznej, lub przeciwko członkowi takiej grupy, jeśli czyny takie mogą podburzać do przemocy lub wzbudzać nienawiść skierowaną przeciwko tej grupie lub jej członkowi;

4) publiczne aprobowanie, negowanie lub rażące pomniejszanie zbrodni określonych $\mathrm{w}$ art. 6 Karty Międzynarodowego Trybunału Wojskowego załączonej do Porozumienia londyńskiego z dnia 8 sierpnia 1945 r., a skierowanych przeciwko grupie osób, którą definiuje się według rasy, koloru skóry, wyznawanej religii, pochodzenia albo przynależności narodowej lub etnicznej, lub przeciwko członkowi takiej grupy, jeśli czyny takie mogą podburzać do przemocy lub wzbudzać nienawiść skierowaną przeciwko tej grupie lub jej członkowi ${ }^{19}$.

Warto od razu zwrócić uwagę, iż przytoczone definicje - co charakterystyczne dla prawa europejskiego - do kategorii przestępstw mowy nienawiści zaliczają zjawisko negacjonizmu ${ }^{20}$. Jednocześnie jednak tak zdefiniowana mowa nienawiści ograniczona jest wyłącznie do takich kryteriów, jak rasa, kolor skóry, wyznawana religia, pochodzenie albo przynależność narodowa lub etniczna. Jedynie w preambule zaznacza się, że państwa członkowskie mogą dodać inne powody, jak np. status społeczny czy przekonania polityczne (pkt 10 preambuły).

Jedną z najnowszych definicji mowy nienawiści można odnaleźć w dokumentach Agencji Praw Podstawowych Unii Europejskiej (FRA), w których wskazano, iż termin „mowa nienawiści” odnosi się do podburzania i zachęcania do nienawiści, dyskryminacji lub wrogości wobec jakiejkolwiek osoby, wynikających z uprzedzeń wobec tej osoby z powodu jakiejś cechy charakterystycznej, np. orientacji seksualnej lub tożsamości płciowej ${ }^{21}$.

19 Decyzja ramowa Rady 2008/913/WSiSW z dnia 28 listopada 2008 r. w sprawie zwalczania pewnych form i przejawów rasizmu i ksenofobii za pomocą środków prawnokarnych, s. 56 (Dz.U. Unii Europejskiej L 328 z 6 grudnia 2008 r.), http://eur-lex.europa.eu/LexUriServ/LexUriServ.do?u ri=OJ:L:2008:328:0055:0058:pl:PDF (dostęp: 15.01.2017).

${ }^{20} \mathrm{Na}$ temat negacjonizmu i sporów wokół przepisów penalizujacych negację Holokaustu zob. szerzej: M. Urbańczyk, Liberalna doktryna wolności słowa a swoboda wypowiedzi historycznej, Poznań 2009; idem, Kwestionowanie Holokaustu. Granice wolności stowa i jej granice w kontekście wypowiedzi historyczno-politycznych, [w:] Konstytucjonalizm a doktryny politycznoprawne. Najnowsze kierunki badań, red. R.M. Małajny, Katowice 2008, s. 279-290; idem, Polemiki: czy karać za kłamstwo oświęcimskie?, „Rzeczpospolita” 21-22 maja 2008, http://www.rp.pl/artykul/137135.html?page=2 (dostęp: 1.05.2017), s. C8; idem, Protokót dodatkowy do Konwencji o cyberprzestępczości jako przykład europeizacji polskiego prawa karnego, [w:] Prawo wobec wyzwań współczesności, red. P. Wiliński, N. Buchowska, B. Guzik, t. 5, Poznań 2008, s. 409-416.

${ }^{21}$ Mowa nienawiści i przestęstwa z nienawiści wobec osób LGTB, http://fra.europa.eu/sites/default/files/fra_uploads/1226-Factsheet-homophobia-hate-speech-crime_PL.pdf (dostęp: 15.03.2017). 
Analizując te, łatwo zauważyć ich ewolucję w kierunku coraz większej liczby przesłanek nietolerancji i dyskryminacji. Jednym z podstawowych problemów wskazywanym w czasie debat nad zwalczaniem mowy nienawiści jest ograniczona liczba przesłanek zawarta w art. 256 i 257 k.k. W tym kontekście należy przywołać definicję zawartą $\mathrm{w}$ raporcie będącym efektem monitorowania treści antysemickich i rasistowskich, mimo że z racji zadania dotyczył on zawężonego pola badawczego (treści wyłącznie ksenofobicznych i rasistowskich). Jego autorzy wskazali, iż mowa nienawiści to wypowiedzi zawierające treści rasistowskie - wypowiedź, która obraża, znieważa, wyszydza, ośmiesza, poniża, demonizuje osoby ze względu na ich przynależność do danej rasy lub pochodzenia etniczne; propaguje lub usprawiedliwia idee lub teorie o wyższości jednej rasy lub grupy osób określonego koloru skóry lub pochodzenia etnicznego, propaguje lub usprawiedliwia nienawiść i dyskryminacje rasową w jakiejkolwiek postaci bądź też podżega do dokonywania wszelkich aktów przemocy na tym tle 22 .

W literaturze podkreśla się, że w obecnym stanie prawnym tworzy się z kolei „hierarchia ochrony ofiar mowy nienawiści”" ${ }^{23}$. Stąd też w debacie publicznej pojawiają się liczne próby zbudowania takiej definicji, która uwzględniałaby wszystkie powody, dla których może mieć miejsce mowa nienawiści. Przykładowo, Dorota Śledzińska-Simon uznała, że

mowa nienawiści to wypowiedź pisemna, ustna lub symboliczna, która czyni przedmiotem ataku jednostkę lub grupę osób ze względu na kryterium rasy, pochodzenia etnicznego, narodowego, religii, języka, płci, wieku, niepełnosprawności, cech zewnętrznych, orientacji seksualnej i tożsamości płciowej, statusu społecznego czy przekonań politycznych. Mowa nienawiści może zastraszać, grozić poniżać, obrażać, a także utrwalać stereotypy i prowadzić do dyskryminacji, a nawet przemocy fizycznej ${ }^{24}$.

Podobnie uzupełnioną wersję własnej definicji przedstawiła Monika Płatek, która wskazała, że „kategoria przestępstw z nienawiści obejmuje narodowość, wyznanie lub jego brak, pochodzenia etniczne, rasowe, orientację seksualną, gender, transgender i niepełnosprawność" 25 . W innym miejscu do tych przesłanek dołożyła „stan zdrowia (HIV/AIDS, narkomania)” oraz „przynależność polityczną" i ,sytuację społeczną danej osoby lub grupy społecznej”26, czyli np. bieda czy bezdomność 27 . Ponadto „uwzględnia również odczucia osoby pokrzywdzonej”. Dzięki temu tak ujęta definicja mowy nienawiści nie przeciwstawia praw jednostki władztwu państwowemu, jednak zobowiązuje władzę państwową do uznania

22 A. Gliszczyńska, K. Sękowska-Kozłowska, R. Wieruszewski, Monitorowanie treści rasistowskich, ksenofobicznych $i$ antysemickich $w$ polskiej prasie, Poznań 2007, http://bezuprzedzen. org/doc/Monitorowanie_tresci_rasistowskich_i_ksenofobicznych[1].pdf, s. 13.

23 D. Śledzińska-Simon, op. cit., s. 93.

24 Ibidem, s. 94.

25 M. Płatek, op. cit., s. 56.

26 Ibidem, s. 57.

27 Ibidem, s. 86. 
podmiotowego prawa jednostki — tak aby władza była zobowiązana działać na rzecz ochrony jednostki ${ }^{28}$. Według M. Płatek istotą przestępstw motywowanych nienawiścią jest fakt, że ofiary należą do danej grupy, nie zaś to, co rzeczywiście ofiary zrobily ${ }^{29}$.

Jedną z pierwszych definicji, która próbowała sprostać wymaganiom kompletności przesłanek nawoływania do nienawiści, jest ta, którą można odnaleźć w raporcie z 2003 r. Biura Studiów i Ekspertyz Kancelarii Sejmu. Mowa nienawiści została tam określona jako:

wypowiedzi ustne i pisemne oraz przedstawienia ikoniczne lżące, oskarżające, wyszydzające i poniżające grupy i jednostki z powodów po części od nich niezależnych — takich jak przynależność rasowa, etniczna i religijna, a także płeć, preferencje seksualne, kalectwo, czy przynależność do „naturalnej” grupy społecznej, jak mieszkańcy pewnego terytorium, reprezentanci określonego zawodu, mówiący określonym językiem. Jest to upubliczniona przemoc werbalna wyraz nienawiści kolektywnej, adresowanej do zbiorowości naturalnych, wyznaczonych przez rasę, narodowości, płeć i wyznanie, do których nie przynależy się z racji swobodnie wybieranych przekonań ${ }^{30}$.

Natomiast jedną z pierwszych definicji mowy nienawiści na gruncie polskim w 2001 r. ukuli Sergiusz Kowalski i Magdalena Tulli, wskazując, że mowa nienawiści

obejmuje wypowiedzi (ustne i pisemne) i przedstawienia ikoniczne lżące, oskarżające, wyszydzające i poniżające grupy i jednostki z powodów po części przynajmniej od nich niezależnych — takich jak przynależność rasowa, etniczna i religijna, a także płeć, preferencje seksualne, kalectwo czy przynależność do „naturalnej” grupy społecznej, jak mieszkańcy pewnego terytorium, reprezentanci określonego zawodu, mówiący określonym językiem itp. ${ }^{31}$

Jest to definicja powszechnie uznawana ${ }^{32}$ przez organizacje pozarządowe zajmujące się monitoringiem i zwalczaniem przejawów rasizmu, antysemityzmu, ksenofobii i innych form dyskryminacji i nietolerancji, która powtarza się w ich publikacjach.

28 Ibidem, s. 57.

29 Oni sami są sprawcom obojętni. Sprawcy mają do nich stosunek całkiem indyferentny i w rzeczywistości nie odczuwają wobec indywidualnych poszkodowanych osobistej nienawiści, najczęściej nawet ich nie znają (ibidem, s. 83).

30 S. Łodziński, Problemy dyskryminacji osób należących do mniejszości narodowych i etnicznych $w$ Polsce (polityka państwa, regulacje prawne i nastawienie społeczne), Biuro Studiów i Ekspertyz Kancelarii Sejmu, Warszawa 2003, s. 5.

31 Mowa nienawiści. Raport 2001, oprac. i wprow. S. Kowalski, M. Tulli, http://or.icm.edu.pl/ monitoring3.htm (dostęp: 15.03.2017).

32 W nieco zmodyfikowanej wersji znaleźć ją można w raporcie z 2007 r.: ,wypowiedzi i wizerunki lżące, wyszydzające i poniżające grupy i jednostki z powodów całkowicie lub po części od nich niezależnych, takich jak cechy rasowe i etniczne, płeć, preferencje seksualne czy kalectwo, a także przynależność do innych naturalnych grup społecznych. Grupy naturalne to takie, których się nie wybiera, udział w jednych determinowany jest biologicznie (płeć, kolor skóry), w innych (przynależność etniczna, religia, język), społecznie" (A. Gliszczyńska, K. Sękowska-Kozłowska, R. Wieruszewski, op. cit.). 
Wychodząc od takiego rozumienia mowy nienawiści jako wypowiedzi lżącej, wyszydzającej i poniżającej jednostki lub grupy, autorzy Zamiast procesu ${ }^{33}$ uszczegółowili ją w następujących punktach. Przede wszystkim uznali, że

mowa nienawiści adresowana jest do zbiorowości, a nie do jednostek. Nawet jeśli uderza na pozór w konkretnego człowieka, czyni to, redukując go do roli typowego przedstawiciela grupy, której rzekome cechy i motywy zostają mu przypisane bez dyskusji [...]. Kryterium to eliminuje ataki czysto personalne ${ }^{34}$.

\section{Po drugie, mowa nienawiści jest kierowana przeciw}

zbiorowościom szczególnego rodzaju — takim, których się nie wybiera. Są to przede wszystkim grupy naturalne, w których udział jest determinowany biologicznie (kolor skóry, płeć, preferencja seksualna, przynależność etniczna i kalectwo) albo społecznie (język, obywatelstwo, religia, miejsce zamieszkania, [...] zawód, w wielu wypadkach dziedziczony rodzinnie) ${ }^{35}$.

Po trzecie, „mowa nienawiści funkcjonuje w świecie wyobrażonym i sama wyznacza swoje cele". Dla rozpowszechniających nienawistne wypowiedzi nieistotne jest,

czy lżony, wyszydzany i poniżany z powodu należenia do jakiejś zbiorowości rzeczywiście do niej należy [...], gdyż przedmiotem zainteresowania nie są prawdziwi ludzie, tylko wizerunki, mianowane i wyposażone w stereotypowe cechy ${ }^{36}$.

Na koniec Kowalski i Tulli dodają, że w tej definicji nie mieści się agresywne w formie kłamstwo, o ile nie pojawiło się w szerszym, spełniającym powyższe kryteria kontekście. Tak zdefiniowana mowa nienawiści jest znacznie szersza niż przestępstwa opisane w art. 256 i 257 k.k., albowiem — jak autorzy sami przyznali - opisywali „zjawisko znacznie szersze, obejmujące to, co wymyka się sądom i kodeksom, podlega zaś osądowi i sankcjom moralnym" ${ }^{\text {"37. }}$.

W odniesieniu do powyższych rozważań własną definicję przedstawiła Ewa Czykwin. W jej ujęciu mowa nienawiści to

nadmiernie zgeneralizowane, stereotypowe stanowisko czy pogląd o innych, wyrażone bez liczenia się z urażającymi konsekwencjami dla poczucia godności osób i kategorii będących jej podmiotem ${ }^{38}$.

Podkreśliła, że tak pojmowane zjawisko służy arbitralnemu, jednostronnemu i uogólnionemu wyrażeniu swojej nienawiści lub niechęci pod „pozorem rzekomego obiektywizmu" zamiast próby zapoczątkowania i podtrzymania dialogu ${ }^{39}$.

33 Książka jest rozszerzoną i uaktualnioną wersją raportu w 2001 r. S. Kowalski, M. Tulli, Zamiast procesu. Raport o mowie nienawiści, Warszawa 2003.

34 Ibidem, s. 21.

35 Ibidem, s. 21-22.

36 Ibidem, s. 22.

37 Ibidem.

38 E. Czykwin, Stygmat społeczny, Warszawa 2007 s. 375.

39 Ibidem. 
Mowa nienawiści nie ma bowiem na celu zadzierzgnięcia i potrzymania dialogu, lecz arbitralne, jednostronne i uogólnione wyartykułowanie własnej nienawiści bądź niechęci pod pozorem rzekomego obiektywizmu. Skutkiem tak definiowanego zjawiska jest podkreślenie rozróżnienia na „swoich” i „innych”. Czykwin dodała także, że

mowę nienawiści można określić też jako dyskursy arbitralne, rzekomo demaskatorskie, pozamerytoryczne i formułowane $\mathrm{w}$ intencji poinformowania widzów o domniemanych niegodziwościach $\mathrm{Obcych}^{40}$.

$\mathrm{Za}$ istotne novum należy uznać tezę, jaką postawiła badaczka, uznając, iż mowa nienawiści nie musi dotyczyć naturalnych grup (o których pisali Kowalski i Tulli). Może bowiem dotyczyć

rodziców adoptujących dziecko, śmieciarzy, pracowników zakładów pogrzebowych, czyszczących szamba, psychiatrów, striptizerek, tancerek go-go, małżeństw decydujących się na poczęcie dziecka metodą in vitro ${ }^{41}$.

W innym ujęciu (na styku socjologii i lingwistyki) Lech Nijakowski wskazał, że mowa nienawiści polega na przypisywaniu szczególnie negatywnych cech lub wzywaniu do dyskryminujących działań wymierzonych w pewną kategorię społeczną, przede wszystkim taką, do której przynależność jest postrzegana jako „naturalna” (przypisana), a nie z wyboru ${ }^{42}$.

Zaprezentował też tzw. wyznaczniki mowy nienawiści:

1) nadmierne uogólnianie negatywnej cechy — negatywne stereotypy grup obcych;

2) przypisywanie szczególnie negatywnych cech - przypisywanie osobom lub grupom szczególnie negatywnych cech lub uczynków;

3) uwłaczająca leksyka, dehumanizacja — analogie, metafory;

4) lekceważenie, podważanie rytuałów poważania — protekcjonalne traktowanie, okazywanie wyższości, niedopuszczanie do głosu;

5) katalogi i zestawienia - katalogi demaskujące „Żydów”;

6) przedmiot nienawiści - mowę nienawiści wyróżnia przedmiot krytyki, zbiorowości, do których przynależność ma charakter przypisany (płeć, kolor skóry, orientacja seksualna, narodowość, etniczność, kalectwo, język ojczysty itp. ${ }^{43}$.

Jednocześnie jednak Lech Nijakowski podkreślił, iż o tym, czy dana wypowiedź ma charakter mowy nienawiści, decyduje kontekst społeczny: „neutralny tekst $\mathrm{w}$ jednym kontekście, $\mathrm{w}$ innym nabiera zupełnie nowego wymiaru i odbierany jest jako skrajnie rasistowski" ${ }^{4}$.

40 Ibidem.

41 Ibidem.

${ }^{42}$ L.M. Nijakowski, Mowa nienawiści w świetle teorii dyskursu, [w:] Analiza dyskursu w socjologii i dla socjologii, red. A. Horolets, Warszawa 2008, s. 133.

43 Ibidem, s. 117-127.

44 Ibidem, s. 128. 
Definicje mowy nienawiści pojawiają się także w kontekście etyki słowa. W takim ujęciu pisała o niej Anna Cegieła. Wskazała, że termin ten odnoszony jest do kilku różnych agresywnych zachowań językowych, odmiennych pod względem rodzaju ekspresji oraz jej natężenia: może to być dyskredytacja, uwłaczanie, chamstwo oraz dyskryminacja mniejszości. W potocznym pojmowaniu mowa nienawiści to

wypowiedź lżąca, szydząca, poniżającą lub obraźliwa. W tym sensie do mowy nienawiści należą wszystkie językowe aspekty obrażania, pogardy, kpiny, drwiny, zniewagi, szyderstwa, ośmieszania, upokarzania, groźby, a niekiedy nawet wyrazistej i dosadnej krytyki ${ }^{45}$.

Według Cegieły ekspresja negatywnych takich uczuć, jak złość, niechęć czy nienawiść, realizowana z zamiarem wyrządzenia szkody na publicznym wizerunku przeciwnika oraz budzenie nienawiści do niego to trzy odmienne działania językowe. Podkreśliła, iż wyrażanie negatywnych uczuć to raczej efekt braku kontroli nad emocjami lub braku umiejętności interakcyjnych, jednocześnie wskazując, że nie w każdym przypadku możliwe jest określenie przez samego wypowiadającego uczuć, które powodują jego nieetyczne zachowania językowe. W dodatku nie w każdym przypadku fundamentem agresywnego słownictwa jest nienawiść. Jak zauważyła,

agresja ma swoje źródło także we frustracji. Działanie z premedytacją, także to, które ma wywołać nienawiść, nosi cechy agresji instrumentalnej — jest nastawione na konkretne korzyści nadawcy komunikatów. Ma zatem taktyczny, a język jest nim traktowany jako narzędzie pokonywania przeciwnika i wykluczania go w rywalizacji ${ }^{46}$.

Jak jednak przyznała, mowa nienawiści to termin zbyt szeroki, nieprecyzyjny, który nie oddaje istoty rzeczy ${ }^{47}$, stąd też zaproponowała posługiwanie się terminem ,strategia wykluczania”. W dalszym swych rozważaniach Cegieła wskazała na istotny element, pisząc iż

retoryka nienawiści albo strategia wykluczenia opiera się właśnie na założeniu, że Innemu nie przysługuje autonomia ani suwerenność. Tym samym odbiera się Innemu podmiotowośćc ${ }^{48}$.

Mowa nienawiści wykorzystywana jest w rywalizacji i sporach publicznych prowadzonych w sposób nieetyczny, gdy język jest regularnie i z premedytacją wykorzystywany jako narzędzie ataku i kreowania gwałtownych negatywnych emocji, które mają wpływ na tworzenie się wrogich postaw wobec ludzi. Mowa

45 A. Cegieła, op. cit., s. 115.

46 Ibidem, s. 116.

47 „Po pierwsze odnosi się go do zjawisk niejednorodnych, z których nie wszystkie dobrze zbadano, takich jak agresja słowna, fałszywa atrybucja czy tendencyjność w wartościowaniu. Po drugie nie jest dobrze rozumiany. Nie wiadomo, czy chodzi o ekspresję nienawiści, czy o jej wywoływanie. Po trzecie używa się go potocznie w funkcji, której mieć nie powinien, czyli jako nieuzasadnionego zarzutu lub oskarżenia stosowanego wobec dyskutanta, który się nie zgadza z rozmówcą lub krytycznie się do niego odnosi" (ibidem, s. 115).

48 Ibidem, s. 58. 
nienawiści staje się wtedy elementem strategii walki za pomocą słowa, strategii wykluczania 49 .

Definiując strategię wykluczania, Cegieła wskazała, iż obejmuje ona

takie działania językowe, które pozbawiają Drugiego szacunku, budzą pogardę dla niego, czynią z niego wroga oraz kształtują przekonanie, że stanowi on zagrożenie dla akceptowanego porządku społecznego i należy ograniczyć mu pole działania we wspólnocie lub z niej wykluczyć. Na strategię wykluczania składają się retoryka pogardy i retoryka zagrożenia ${ }^{50}$.

Inną propozycję przedstawiła w swych tekstach Jadwiga Linde-Usiekniewicz. Jako narzędzie opisu tego, czym jest mowa nienawiści, zaproponowała teorię relewancji ${ }^{51}$. W swych rozważaniach wyszła od porównania dwóch definicji zaczerpniętych z literatury anglosaskiej. Pierwsza określa mowę nienawiści jako podburzanie do nienawiści lub dyskryminacji ze względu na przynależność do pewnej grupy, (określonej przez) rasę, pochodzenie, religię, orientację seksualną lub płeć ${ }^{52}$. W drugiej - słownikowej — wskazuje się, że jest to mowa atakująca osobę lub grupę osób z powodu rasy, religii, płci, orientacji seksualnej itp. ${ }^{53} \mathrm{Za}$ trafne i istotne spostrzeżenie należy uznać stwierdzenie Linde-Usiekniewicz, iż

różnica między tymi dwoma ujęciami sprowadza się do tego, że ewentualnym adresatem podburzania $[\ldots]$ mogą być $[\ldots]$ tylko osoby nienależące do wymienionej w definicji grupy; adresatami ataku mogą być i są osoby lub grupy osób, których mowa nienawiści dotyczy ${ }^{54}$.

Za równie ważne wypada uznać wskazanie, że mowa nienawiści dotyczy grup, które stanowią mniejszość w społeczeństwie, jednak swoiście pojmowaną, tj. jako te części społeczeństwa, którym władza odmawia przyznania praw, jakimi cieszą się inne grupy. W ten sposób - jak zauważa Linde-Usiekniewicz — „wypowiedzi zawierające elementy wrogości lub nawet nienawiści wobec uprzywilejowanej większości nie są uważane za przejawy mowy nienawiści" 55

49 Ibidem, s. 114.

50 Ibidem. Warto zaznaczyć, że w innym (wcześniejszym) tekście pt. Czym jest mowa nienawiści? Cegieła stosowała termin „strategia nienawiści”; zob. szerzej eadem, Czym jest mowa nienawiści?, „Poradnik Językowy” 2014, z. 1, s. 7 n.

51 Szerzej na ten temat zob. J. Linde-Usiekniewicz, Teoria relewancji jako narzędzie opisu mowy nienawiści, „Studia Pragmalingwistyczne” 7, 2015, nr 7, s. 51-66, i zawarta tam literatura; eadem, Towards a Relevance Theory Account of Hate Speech, niepublikowany referat wygłoszony na VII międzynarodowej konferencji „Interpreting for Relevance: Discourse and Translation”, 29-30 września 2014 r., Instytut Anglistyki Uniwersytetu Warszawskiego. Warto także wskazać na koncepcję J. Linde-Usiekniewicz opisywania nawoływania do nienawiści w świetle teorii aktów mowy J. Austina; szerzej zob. eadem, Wybrane problemy rozpoznawania językowych cech ,nawoływania do nienawiści, http://www.otwarta.org/wp-content/uploads/2015/07/EKSPERTYZA-J\%C4\%98ZYKOZNAWCZA_J.-Linde-Usiekniewicz.pdf (dostęp: 1.05.2017).

52 J. Linde-Usiekniewicz, Teoria relewancji..., s. 52.

53 Ibidem.

54 Ibidem.

55 Ibidem, s. 53. 
(choć jednocześnie warto zastanowić się, w jakim stopniu zasadne jest takie „dyskryminowanie" większości).

W dalszej części Linde-Usiekniewicz wskazała, że dla mowy nienawiści w przyjętym przez nią zakresie

istotne jest, by stanowiła zachowanie komunikacyjne i żeby atakowała osobę lub grupę osób ze względu na przynależność do jakiejś grupy, określonej ze względu na rasę, pochodzenie etniczne [...], przy czym katalog tych cech traktuję [Linde-Usiekniewicz — przyp. E.R., M.U.] jako otwarty w tym sensie, że niezależnie od stanu prawnego [...] lista owych grup musi obejmować po prostu grupy dyskryminowane ${ }^{56}$.

Niejako przy okazji tych rozważań Linde-Usiekniewicz wprowadziła (za Beneschem) dodatkowe pojęcie tzw. mowy niebezpiecznej (dangerous speech), czyli podżegania do ludobójstwa ${ }^{57}$. Warto dodać, że tego typu wypowiedzi są penalizowane w polskim kodeksie karnym w art. 126a k.k. w związku z art. 118 k.k. (pochwalanie lub nawoływanie do popełniania zbrodni ludobójstwa).

Stosując narzędzia teorii relewancji do rozpoznawania i opisu mowy nienawiści, Linde-Usiekniewicz uznała, że

mową nienawiści jest taka wypowiedź, do której optymalnego przetwarzania niezbędne są przesłanki (czyli przekonania lub reprezentacje przekonań) dotyczące tego, że jakaś grupa w tej wypowiedzi przywołana i zdefiniowana przez cechy uznane za stałe - jest gorsza pod jakimś względem, a przez to zasługuje na gorsze traktowanie, i że osoba lub osoby, do których się ta wypowiedź odnosi, należą do tej grupy ${ }^{58}$.

W literaturze przedmiotu można też znaleźć inne definicje mowy nienawiści, odchodzące od tradycyjnego ujęcia. Przykładowo określenie jej jako „różne typy emocjonalnie negatywnych wypowiedzi, wymierzonych przeciwko grupom, które opisuje się jako »gorsze«"59. Jest to jednak definicja zbyt ogólna i za szeroka.

W podobnie opisowy sposób Robert Biedroń nazywa mowę nienawiści językiem presji i opresji ${ }^{60}$. W innym miejscu w sposób bardziej szczegółowy wskazuje, że

mową nienawiści (ang. hate speech) nazywane są różne typy negatywnych emocjonalnie wypowiedzi, wymierzonych przeciwko grupom lub jednostkom ze względu na domniemaną lub faktyczną przynależność do grupy, powstających na bazie uprzedzeń. Opis grup jako gorszych i niepełnowartościowych może zarówno przyzwalać na przemoc i zachęcać do niej, jak i usprawiedliwiać jej stosowanie ${ }^{61}$.

56 Ibidem.

57 Ibidem.

58 Ibidem, s. 63.

59 E. Ryłko, Jak mówić o przestępstwach z nienawiści?, [w:] Przemoc motywowana uprzedzeniami..., s. 11.

${ }^{60}$ R. Biedroń, Wprowadzenie do raportu, [w:] Raport o homofobicznej mowie nienawiści w Polsce, red. G. Czarnecki, Warszawa 2009, s. 7.

61 R. Biedroń, Koncepcja przestęstw z nienawiści, [w:] Przemoc motywowana nienawiścia, red. M. Makuchowska, Warszawa 2011, s. 16. 
Próbę stworzenia spójnej definicji podjęto również w raporcie Mowa nienawiści w przestrzeni publicznej. Raport z badań prasy w 2014 roku, w którym

za akt mowy nienawiści uznano [...] wypowiedź, która szerzy, propaguje i usprawiedliwia nienawiść rasową, ksenofobię, antysemityzm oraz inne formy nietolerancji podważające bezpieczeństwo demokratyczne, spoistość kulturową i pluralizm. Aby dana wypowiedź mogła być uznana za przykład mowy nienawiści, musiała spełniać łącznie trzy warunki:

a) być wypowiadana z negatywną intencją lub z zamierzeniem ataku (poniżenia, zdeprecjonowania, obrażenia, pokazania wyższości etc.),

b) być skierowana do zbiorowości lub do osoby indywidualnej zredukowanej do cechy danej zbiorowości,

c) używać cechy będącej elementem czyjejś tożsamości (lub przypisywać danej osobie taką cechę) jako epitetu/etykiety będących podstawą do dyskryminacji ${ }^{62}$.

Za potencjalne płaszczyzny dyskryminacji uznano pochodzenie etniczne, narodowość, wyznanie, płeć, orientację seksualną, wiek i niepełnosprawność ${ }^{63}$.

Podsumowując owe rozważania, warto pamiętać, że

język, za pomocą którego posługujemy się każdego dnia, kształtuje społeczną świadomość. Słowa nadają rzeczom cechy, oceniają, wartościują. Nazywając, tworzymy rzeczywistość, która nieopisana, po prostu nie istnieje. Dlatego tak ważny jest sposób, za pomocą którego opisujemy nasz świat oraz innych ${ }^{64}$.

Wobec wspomnianych problemów definicyjnych istnieje obawa, że coraz częstsze próby jak najszerszego definiowania mowy nienawiści oraz idące za tym głosy o konieczności nowelizacji prawa karnego mogą jednak nie przynieść spodziewanych skutków. Prawo, zwłaszcza prawo karne, powinno bowiem „służyć jako wsparcie polityki społecznej kreującej wrażliwość i wzory politycznej poprawności, ale nie może takiej polityki zastąpić" 65 .

W tym kontekście można wysnuć kilka wniosków. Po pierwsze, widać pewną ewolucję, polegającą na zwiększaniu płaszczyzn dyskryminacji. Do początkowych przesłanek mowy nienawiści, takich jak rasa, narodowość, przynależność etniczna i wyznanie lub bezwyznaniowość, dochodzą dziś kolejne w postaci płci, orientacji seksualnej, tożsamości płciowej, niepełnosprawności, wieku, stanu zdrowia, a nawet przekonań politycznych. Pojawiają się także definicje zawierające katalogi otwarte, w których nie wskazuje się, jakie grupy mogą być przedmiotem ataku. Taka tendencja musi budzić zaniepokojenie z punktu widzenia wolności słowa i jej granic. Bezsprzecznie godność człowieka jest wartością, którą prawo powinno chronić, nie może to jednak następować kosztem istoty innych

62 Mowa nienawiści w przestrzeni publicznej. Raport z badań prasy w 2014 roku - streszczenie, oprac. A. Bulandra, J. Kościółek, www.interkulturalni.pl/plik.php?id=128 (dostęp: 1.05.2017), s. 2-3.

${ }^{63}$ Mowa nienawiści w przestrzeni publicznej. Raport z badań prasy w 2014 roku, red. A. Kościółek, Kraków 2015, s. 56.

64 R. Biedroń, Wprowadzenie do raportu..., s. 7.

65 M. Płatek, op. cit., s. 66. 
fundamentalnych praw i wolności demokratycznych, jak np. prawo do swobody wypowiedzi. Tendencje w dyskursie społeczno-politycznych mogą temu zagrozić. Trzeba bowiem pamiętać, że demokracja nie daje nam prawa do bycia nieobrażanym. Z drugiej strony nie można zapominać o tzw. piramidzie nienawiści Gordona Allporta, czyli pięciostopniowej skali uprzedzeń, będącej modelem zachowań ksenofobicznych, w której pierwszym stopniem jest rozpowszechnianie negatywnych wypowiedzi zawierających stereotypy i uprzedzenia, a ostatnim ludobójstwo.

Punktem wyjścia do dalszych badań jest następująca typologia czy też uproszczony podział na mowę nienawiści w wąskim znaczeniu i mowę nienawiści w znaczeniu szerokim. W pierwszym wypadku mowa wyłącznie o przestępstwach określonych w polskim kodeksie karnym (najczęściej przyjmuje się, że chodzi tu o przestępstwo propagowania faszystowskiego lub innego totalitarnego ustroju państwa lub nawoływanie do nienawiści [art. 256 k.k.] i znieważenie grupy ludności albo poszczególnej osoby z powodu jej przynależności narodowej, etnicznej, rasowej, wyznaniowej albo z powodu jej bezwyznaniowości [art. 257 k.k.] $)^{66}$. W znaczeniu szerokim mowa nienawiści to każda wypowiedź w sferze publicznej, która ma charakter znieważający, poniżający lub która w swej treści nawołuje do nienawiści w stosunku do kogoś z powodu jego przynależności do określonej grupy (np. niepełnosprawność czy wiek).

Konkluzją jest stwierdzenie, iż niezgoda co do zakresu penalizowania mowy nienawiści (a nawet wcześniejsza niezgoda co do zdefiniowania samego zjawiska) jest efektem diametralnych różnic między wartościami, argumentami a ideami, przywoływanymi przez uczestników szeroko rozumianej publicznej debaty społeczno-politycznej o mowie nienawiści, której istotnymi elementami są prawo, doktryna prawa i orzecznictwo sądów. Warto jednak tę hipotezę badawczą sprawdzić w dalszych pracach badawczych.

\section{Bibliografia}

Biedroń R., Koncepcja przestępstw z nienawiści, [w:] Przemoc motywowana nienawiścia, red. M. Makuchowska, Warszawa 2011.

Biedroń R., Wprowadzenie do raportu, [w:] Raport o homofobicznej mowie nienawiści w Polsce, red. G. Czarnecki, Warszawa 2009.

Bilewicz M. et al., Mowa nienawiści. Raport z badań sondażowych, Warszawa 2014.

66 Kwestią dyskusyjną jest zaliczenie do tej grupy innych przestępstw z kodeksu karnego i innych ustaw karnych, takich jak nawoływanie do popełnienia przestępstwa (art. 255 k.k.), pochwalanie lub nawoływanie do popełniania zbrodni ludobójstwa (art. 126a k.k. w zw. z art. 118 k.k.), nawoływanie do popełnienia przestępstwa masowego zamachu (art. 126a zw. z art. 118a k.k.), obraza uczuć religijnych (art. 196 k.k.), tzw. kłamstwo oświęcimskie (art. 55 ustawy z 18 grudnia 1998 r. o Instytucie Pamięci Narodowej — Komisji Ścigania Zbrodni przeciwko Narodowi Polskiemu; Dz.U. z 1998 r. Nr 155, poz. 1016 z późn. zm. 
Cegieła A., Czym jest mowa nienawiści?, „Poradnik Językowy” 2014, z. 1.

Cegieła A., Stowa i ludzie, Warszawa 2014.

Czykwin E., Stygmat spoteczny, Warszawa 2007.

Decyzja ramowa Rady 2008/913/WSiSW z dnia 28 listopada 2008 r. w sprawie zwalczania pewnych form i przejawów rasizmu i ksenofobii za pomocą środków prawnokarnych (Dz.U. Unii Europejskiej L 328 z 6 grudnia 2008 r.), http://eur-lex.europa.eu/LexUriServ/LexUriServ. do?uri=OJ:L:2008:328:0055:0058:p1:PDF.

Free Speech, edycja II, http://prawo.amu.edu.pl/strona-glowna/jednostki-organizacyjne/katedry/ Katedra-Doktryn-Polityczno-Prawnych-i-Filozofii/freespeechpoznan-edycja-ii.

Gliszczyńska A., Sękowska-Kozłowska K., Wieruszewski R., Monitorowanie treści rasistowskich, ksenofobicznych i antysemickich w polskiej prasie, Poznań 2007, http://bezuprzedzen.org/doc/ Monitorowanie_tresci_rasistowskich_i_ksenofobicznych[1].pdf.

Hate crime and the law. A briefing paper, Anti-Bullying Alliance, London 2016.

Hate Crime Operational Guidance, College of Policing Limited, Coventry 2014.

Homophobic hate crimes and hate incidents. Equality and Human Rights Commission 2009. Responding to Hate Crime. A Multidisciplinary Curriculum, National Center for Hate Crime Prevention, Washington 2000.

Konwencja Rady Europy o cyberprzestępczości, sporządzona w Budapeszcie 23 listopada $2001 \mathrm{r}$. (Dz.U. z 2015 r., poz. 728).

Kowalski S., Obecność mowy nienawiści w życiu społecznym i debacie publicznej, [w:] Mowa nienawiści a wolność stowa. Aspekty prawne i społeczne, red. R. Wieruszewski et al., Warszawa 2010.

Kowalski S., Tulli M., Zamiast procesu. Raport o mowie nienawiści, Warszawa 2003.

Krotoszyński M., Trzecia droga: środki administracyjne $w$ zwalczaniu mowy nienawiści, [w:] Mowa nienawiści a wolność stowa. Aspekty prawne i społeczne, red. R. Wieruszewski et al., Warszawa 2010.

Linde-Usiekniewicz J., Teoria relewancji jako narzędzie opisu mowy nienawiści, „Studia Pragmalingwistyczne" 7, 2015, $\mathrm{nr} 7$.

Linde-Usiekniewicz J., Towards a Relevance Theory Account of Hate Speech, niepublikowany referat wygłoszony na VII międzynarodowej konferencji „Interpreting for Relevance: Discourse and Translation", 29-30 września 2014 r., Instytut Anglistyki Uniwersytetu Warszawskiego.

Linde-Usiekniewicz J., Wybrane problemy rozpoznawania językowych cech , nawotywania do nienawiści", http://www.otwarta.org/wp-content/uploads/2015/07/EKSPERTYZA-J\%C4\%98ZYKOZNAWCZA_J.-Linde-Usiekniewicz.pdf.

Łodziński S., Problemy dyskryminacji osób należacych do mniejszości narodowych i etnicznych $w$ Polsce (polityka państwa, regulacje prawne i nastawienie społeczne), Biuro Studiów i Ekspertyz Kancelarii Sejmu, Warszawa 2003.

Mowa nienawiści i przestępstwa z nienawiści wobec osób LGTB, http://fra.europa.eu/sites/default/ files/fra_uploads/1226-Factsheet-homophobia-hate-speech-crime_PL.pdf.

Mowa nienawiści w przestrzeni publicznej. Raport z badań prasy w 2014 roku - streszczenie, oprac. A. Bulandra, J. Kościółek, www.interkulturalni.pl/plik.php?id=128.

Mowa nienawiści w przestrzeni publicznej. Raport z badań prasy w 2014 roku, red. A. Kościółek, Kraków 2015.

Mowa nienawiści. Raport 2001, oprac. i wprow. S. Kowalski, M. Tulli, http://or.icm.edu.pl/ monitoring $3 . \mathrm{htm}$.

Nijakowski L.M., Mowa nienawiści w świetle teorii dyskursu, [w:] Analiza dyskursu w socjologii $i$ dla socjologii, red. A. Horolets, Warszawa 2008.

Oświadczenie Rządowe z 2 kwietnia 2015 r. w sprawie mocy obowiązującej Konwencji o cyberprzestępczości (Dz.U. z 2015 r. poz. 729).

Pałka K., Kućka M., Ochrona przed mowa nienawiści - powództwo cywilne czy akt oskarżenia?, [w:]

Studia nad Autorytaryzmem i Totalitaryzmem 39, nr 2, 2017

(C) for this edition by CNS 
Mowa nienawiści a wolność słowa. Aspekty prawne i spoleczne, red. R. Wieruszewski et al., Warszawa 2010.

Piskorski J., Polityzacja mowy nienawiści, niepublikowany referat wygłoszony w czasie II Międzynarodowej Konferencji „W poszukiwaniu europejskiej doktryny wolności słowa”, 23-24 marca 2017 r., Wydział Prawa i Administracji Uniwersytetu im. Adama Mickiewicza w Poznaniu.

Płatek M., Mowa nienawiści - przesłanki depenalizacji, [w:] Mowa nienawiści a wolność słowa. Aspekty prawne i spoleczne, red. R. Wieruszewski et al., Warszawa 2010.

Preventing and responding to hate crimes, OSCE - ODIHR, Warszawa 2009.

Protokół dodatkowy do Konwencji Rady Europy o cyberprzestępczości dotyczący penalizacji czynów o charakterze rasistowskim lub ksenofobicznym popełnionych przy użyciu systemów komputerowych, sporządzony w Strasburgu dnia 28 stycznia 2003 r. (Dz.U. z 2015 r. poz. 730).

Przegląd, Międzynarodowa Konferencja pt. „,W poszukiwaniu europejskiej doktryny wolności stowa", https://www.tygodnikprzeglad.pl/miedzynarodowa-konferencja-pt-poszukiwaniu-europejskiej-doktryny-wolnosci-slowa/.

Przemoc motywowana uprzedzeniami. Przestępstwa z nienawiści, red. A. Lipowska-Teutsch, E. Ryłko, Kraków 2007.

[Redakcja Wprost], Jak ma się mowa nienawiści do wolności słowa? Co wolno napisać nam w internecie? Odpowiedza prawnicy, https://www.wprost.pl/zycie/10046470/II-MiedzynarodowaKonferencja-pt-W-poszukiwaniu-europejskiej-doktryny-wolnosci-slowa.html.

Rekomendacja Komitetu Ministrów Rady Europy nr R97/20, https://rm.coe.int/CoERMPublicCommonSearchServices/DisplayDCTMContent?documentId=0900001680505d5b.

Ryłko E., Jak mówić o przestęstwach z nienawiści?, [w:] Przemoc motywowana uprzedzeniami. Przestępstwa z nienawiści, red. A. Lipowska-Teutsch, E. Ryłko, Kraków 2007.

Szwejkowski Ł., Przestepstwa z nienawiści. Wybrane zagadnienia, materiały dydaktyczne Centrum Szkolenia Policji, Legionowo 2012.

Śledzińska-Simon D., Decyzja ramowa w sprawie zwalczania pewnych form i przejawów rasizmu $i$ ksenofobii jako trudny kompromis wobec mowy nienawiści w Unii Europejskiej, [w:] Mowa nienawiści a wolność słowa. Aspekty prawne i społeczne, red. R. Wieruszewski et al., Warszawa 2010.

Urbańczyk M., Kwestionowanie Holokaustu. Granice wolności słowa i jej granice w kontekście wypowiedzi historyczno-politycznych, [w:] Konstytucjonalizm a doktryny politycznoprawne. Najnowsze kierunki badań, red. R.M. Małajny, Katowice 2008.

Urbańczyk M., Liberalna doktryna wolności stowa a swoboda wypowiedzi historycznej, Poznań 2009;

Urbańczyk M., Polemiki: czy karać za kłamstwo oświęcimskie?, „Rzeczpospolita” 21-22 maja 2008, http://www.rp.pl/artykul/137135.html?page=2.

Urbańczyk M., Protokót dodatkowy do Konwencji o cyberprzestępczości jako przykład europeizacji polskiego prawa karnego, [w:] Prawo wobec wyzwań współczesności, red. P. Wiliński, N. Buchowska, B. Guzik, t. 5, Poznań 2008.

Ustawa z 12 września 2014 r. o ratyfikacji Konwencji o cyberprzestępczości (Dz.U. z 2014 r. poz. 1514).

Ustawa z 18 grudnia 1998 r. o Instytucie Pamięci Narodowej — Komisji Ścigania Zbrodni przeciwko Narodowi Polskiemu (Dz.U. z 1998 r. Nr 155, poz. 1016 z późn. zm.).

Woiński M., Prawnokarne aspekty zwalczania mowy nienawiści, Warszawa 2014.

Wspólne działanie z dnia 15 lipca 1996 r. przyjęte przez Radę na podstawie art. K.3 Traktatu o Unii Europejskiej, dotyczące działania w celu zwalczania rasizmu i ksenofobii, 96/443/WSiSW, (Dz.U. Wspólnot Europejskich L 185/5 z 24 lipca 1996 r.; Dz.U. Unii Europejskiej 19, t. 1), https://bip.ms.gov.pl/Data/Files/_public/bip/prawo_eu/ue2/31996f0443pl.pdf.

Wyrok Sądu Okręgowego w Katowicach z 23 września 2009 roku (sygn. akt III C 286/08).

Studia nad Autorytaryzmem i Totalitaryzmem 39, nr 2, 2017

(C) for this edition by CNS 


\section{THE COMPLEXITY OF THE HATE SPEECH PHENOMENON IN TERMS OF ITS NON-LEGAL DEFINITIONAL ASPECT}

\section{Summary}

The starting point is thinking that the modern political debate manifests in the degradation of the culture of discussion. One of the issues that can be observed next to this phenomenon is the brutalization of the language of public debate - hate speech is becoming more and more common.

The aim of the paper is the description and the characteristic of vital aspects which appear in accordance to the designation of hate speech and its manifestations in public sphere.

Keywords: hate speech, incitement to hatred, hate, freedom of speech, limits of freedom of speech, hate speech, incitement to hatred, hate, fascism, racism, antisemitism, relevance theory, dangerous speech, Gordon Allport, xenophobia, discrimination.

Ewelina Rogalska

ewelinarogalska@yahoo.com

Michał Urbańczyk

mur@amu.edu.pl 